\title{
Local Self-Government Transformations in Ukraine and Reforms of Social Services: Expectations and Challenges
}

\section{Tetyana Semigina ${ }^{1}$}

${ }^{1}$ Academy of Labour, Social Relations and Tourism

3-A Kiltseva Doroha, Kyiv, 03187, Ukraine

DOI: $10.22178 /$ pos.54-1

LCC Subject Category: K7585-7595

Received 28.12.2019

Accepted 28.01.2020

Published online 31.01.2020

Corresponding Author:

Semigina.tv@socosvita.kiev.ua

(C) 2020 The Author. This

article is licensed under a

Creative Commons Attribution

4.0 License @ (1)
Abstract. On January 1, 2020, the Law "On Social Services" comes into force in Ukraine. The new legislation sets up the responsibilities for the executive bodies of city councils, councils of cities of regional significance, councils of united territorial communities, it also introduces the new model of community-based social services provision. The paper analyses this new legislation in the context of the Ukrainian municipal reforms and outlines the challenges that territorial communities may face while ensuring the implementation of legislation.

The new legal regulation focuses on improving the management of the social services system in the context of decentralization and optimizing expenditures, ensuring uniform approaches in the organization of the system. The benefits of the new legislation include the fact that, in order to optimize and integrate social services, complex social service institutions / institutions can be created. According to the legislation, all local communities are obliged to provide a range of basic social services of voluntary and mandatory nature.

The conducted analysis highlights the gaps in the legislation regarding social services provision, including an extensive and not always clear classification of social services to be provided on the local community level; absence of the by-laws necessary to implement the particular norms of the framework Law; unclear financial issues of social services provision; lack of social work professionals able to introduce the fullscale model.

Keywords: local self-government; decentralization; social services; social work.

\section{INTRODUCTION}

In 2014, Ukraine starts a local self-government reform implementation on the new political and legal basis [7]. On the 1st of April 2014, the Government of Ukraine approved the new Concept on Local Self-Government Reform where the territorial communities' cooperation is defined as a key priority for further local sustainable development. Then the Verkhovna Rada (Parliament of Ukraine) adopted a legislative package to extend the powers of the local self-government bodies and to optimize the provision of administrative services. So, the following laws were adopted: The Law of Ukraine "On Cooperation of Territorial Communities" and The Law of Ukraine "On Fundamentals of State Regional Policy". This, according to [9], allowed the delegating of powers to the local authorities, who are now responsible for dealing with the issues of the residence registration; issuance of passports; state registration of legal entities and individuals, entrepreneurs, associations of citizens; civil registration; resolving the land issues, etc. Overall, it was assessed by [10] as "an ambitious decentralization reform".

Some researchers pointed out that the local selfgovernment reform provides for the decentralization and consolidation of the existing territorial communities, and their development [7]. While other academics stress the real development of the regions, because the finances will not be redistributed between the center and periphery, but will be stored in communities for their economic development, education and healthcare purposes [2].

Decentralization processes have challenged the social service delivery system in Ukraine. The question was raised about how the system members should interact in the new legal environment, how the powers between different levels of territorial organizations in the provision of services should be delimited, how to stimulate the development of the social services market on the local level. 
The available data indicates that by now the development of community-based social is largely sporadic in Ukraine due to the lack of funding, lack of legal framework, lack of quality standards or low capacity of the service providers. Where services exist, they are mostly provided by the non-governmental and civil society organizations and are severely under-resourced, especially in rural, remote or deprived areas where needs are the highest. For example, given the lack of support for children and families and the consistently low income within the family, the placement of a child in an institution is often seen as the only possible form of assistance for families which, in fact, only aggravates the situation [4]. There is a demand for the community-based social services that are typical for the European model of local development. At the same time, researchers provide evidence for the necessity of rethinking the financial policy of local selfgovernment bodies in the direction of saving money and provision of social services in order to increase their efficiency and quality, decrease in costs [11].

On January 1, 2020, the new Law "On Social Services" (hereafter - the Law) comes into force [3]. The new law is considered to be one of the components of administrative-territorial reform in Ukraine, since it aims, in particular, at the division of powers in socio-economic spheres between local governments at different levels. However, much of what concerns the provision of social services still remain at a stage of legal uncertainty, especially in consolidated, united territorial communities.

This paper analyses the new social services legislation in the context of the Ukrainian municipal reforms and outlines the challenges that territorial communities face while ensuring the implementation of new legislation. The work was done on the basis of a normative and critical analysis of the adopted legislation, as well as discussions with social work practitioners and representatives of local territorial communities, in particular during the round table "Implementation of the new Law of Ukraine "On social services": tasks for education and practice" held in October 2019 in the Academy of Labour, Social Relations and Tourism (Kyiv, Ukraine).

\section{RESULTS AND DISCUSSIONS}

First of all, it is necessary to point out the Law "On Social Services" (Article 25) sets up new re- sponsibilities for the executive bodies of city councils, councils of cities of regional significance, councils of united territorial communities. They include:

1) determining the needs of the population of the administrative/territorial unit / territorial community in social services, including the involvement of social service providers of the nongovernmental sector, the promulgation of relevant results;

2) informing the population about the list of social services, their contents and the procedure for providing them in a form accessible for perception by persons with any kind of health disorder;

3) implementation of measures for the identification of vulnerable population groups and persons/families in difficult life circumstances;

4) ensuring, as a result of the assessment of the needs of the person/family, the provision of basic social services to persons/families by their needs, taking measures to provide other social services to such persons/families by establishing a network of public/social services providers and/or involvement of non-governmental social service providers (through social contracting, public-private partnership, competition for social projects, social programs, etc.) and/or under the terms of a contract with the competent authorities;

5) approval, provision of financing and implementation of regional programs in terms of meeting the needs of persons/families in social services, developed as a result of determining the needs of the population of the administrativeterritorial unit / territorial community in social services;

6) ensuring the professional competence/qualification of the employees of the social service providers formed by them;

7) coordination of the activities of the actors of the social service delivery system at the local level;

8) ensuring interaction between social service providers and bodies, institutions, institutions, natural persons - entrepreneurs, who, within their competence, provide assistance to vulnerable groups and persons/families in difficult territories within the respective administrative unit / territorial community life circumstances and/or protect them; 
9) collecting, analyzing and disseminating, by the law, information on the provision of social services, promoting the implementation of a better experience in providing social services;

10) maintenance of the Register of providers and recipients of social services at the local level;

11) monitoring of the provision of social services, evaluation of their quality, the promulgation of relevant results;

12) control over the targeted use of budgetary funds aimed at financing social services;

13) exercising control over compliance with the requirements of this Law by the procedure established by the Cabinet of Ministries of Ukraine;

14) ensuring observance of the rights of recipients of social services;

15) the appointment of managers of social service providers created by them, the activities of which are financed at the expense of the relevant budget (s);

16) resolving other issues related to the provision of social services by the Law.

The Article 16 of the Law defines that social services by their aims could be: 1) services aimed at prevention of difficult life circumstances and/or entry of a person/family into such circumstances; 2) social support - help to overcome a person/family's difficult life circumstances; 3) social care - minimizing for the person/family the negative effects of difficult life circumstances, supporting their livelihoods, social status, and community involvement. At the same time, the legislation stipulates that social services by their type could be: 1) simple social services that do not provide permanent or systematic comprehensive assistance (information, counseling, mediation, asylum, representation of interests, etc.); 2) comprehensive social services, which envisage coordinated actions of specialists in providing permanent or systematic comprehensive assistance (care, education, cohabitation, social support, crisis intervention, supported housing, social adaptation, social integration, and reintegration, etc.); 3) comprehensive specialized social services provided to a certain category of recipients of social services (persons with HIV, persons with addiction to psychotropic substances, persons affected by trafficking in persons, refugees, persons with mental disorders and others); 4) ancillary social services provided in the form of natural aid (food, personal hygiene items, sani- tary and cleaning products, care products, clothing, shoes and other necessities, food supply, fuel supply, etc.) and technical services (transport services, sign language translation, etc.).

Moreover, the same article of the Law defines that social services, depending on the place of provision, are divided into services provided: 1) at the place of residence/stay of the recipient of social services (at home); 2) in the premises of the social service provider, either stationary or semi-stationary; 3 ) at the place of residence of the recipient of social services outside the place of residence and premises of the social service provider, including on the street. Also, the Law says that social services, depending on the term of provision, are divided into services provided: 1) emergency (crisis) - immediately (during the day) due to circumstances that threaten the life and/or health of the recipient of social services; 2) constantly - at least once a month for more than one year; 3) temporarily - at least once a month for up to one year; 4) one time. Thus, there is more than one classification of social services in the legislation, which makes it difficult to understand the service system.

While previous legislation postulated the voluntary nature of receiving social services, the new law introduces the concept of non-voluntary services: in some cases, recipients of services cannot refuse them but must undergo individual corrective programs, namely: parents who do not perform parental responsibilities; persons who have committed gender-based violence, domestic abuse or child abuse; persons to whom probation measures are applied by the law; persons sent by the court to a program for offenders; in other cases provided by law. In essence, this implies the obligation for local territorial communities to provide "mandatory" social services designed to perform the function of social control.

The Law sets down that the Kyiv and Sevastopol city state administrations, district, district in Kyiv and Sevastopol state administrations, executive bodies of city councils of cities of regional importance, as well as executive bodies of rural, settlement, city councils of united territorial communities, should ensure the direct provision of the grant social services, namely: home care, daycare; supported accommodation; social adaptation; social integration and reintegration; asylum; emergency (crisis) intervention; consultancy; social support; representation of interests; mediation; social prevention; natural aid; physical sup- 
port of persons with disabilities who have disorders of the musculoskeletal system and move on wheelchairs, impaired vision; sign language translation; care and upbringing of children in conditions close to family; support during inclusive learning; informing. At the same time, it is stated that the local self-government body should take measures to provide not only basic but also other social services.

The Law also specifies that social services may be provided in employment centers, health care facilities, education, culture, etc. The benefits of the new legislation include the fact that to optimize and integrate social services, complex social service institutions/institutions can be created, structured or separated (territorial) subdivisions that provide different social services to different population groups.

A list of social services outlined in the legislation seems rather large. All of these services should be provided in the community, as close as possible to the accommodation of the person who needs them.

It should be noted that the Law establishes uniform requirements for providers of social services of all forms of ownership: state, communal and non-state. Non-governmental social service providers include enterprises, institutions, organizations, public associations, charities, religious organizations, natural persons - entrepreneurs and individuals providing social care services under this law without engaging in entrepreneurial activity. It has been determined that non-governmental sector providers can be involved through social procurement, publicprivate partnerships, competition for social projects, social programs and more. Social contracting, from the legislator's point of view, should be carried out by compensating social service providers for the cost of social services provided by them. As this is regarded as a part of the broader decentralization process, success will depend on both local authorities and civil society.

The relevant amendments have been also done to the Law "On Local Self-government" and seven other Laws of Ukraine. Overall, these amendments and expected new responsibilities could be considered as being in line with the shaping of the European model of local self-government. Since the new legislation provides more regulatory and financial policy tools to local bodies in the provision of social services it could be potentially beneficial for the development of the long- awaited innovative community services in Ukraine.

However, there are a lot of discussions and hesitation if the local self-government and other municipal bodies could execute the new responsibilities, and how a right to social care could be implemented within the new Ukrainian legal regulations.

First of all, the Law possesses a framework of nature. A set of more than 10 by-laws, as well as new procedures, has to be adopted by the Cabinet of Ministries or the Ministry of Social Policy to make the Law come into a real force. As of the 1st of January 2020, such by-laws were not adopted. The Association of Ukrainian Cities draws attention to the fact that the Law of Ukraine 'On Social Services' No. 2671 “cannot be implemented without a partial violation of the law" [1]. It looks like a Catch-22 situation: any activities of the local communities in the provision of social services could be regarded as an illmove and badly perceived by the population and the media.

The Law states that the list of social services provided under the Law is determined by the Social Services Classifier, which is approved by the central executive body, which ensures the formation of state policy in the field of social protection of the population. Such a Classifier has not been created, as well as registers of providers and recipients of social services (such registers are also demanded by the Law).

One of the ambivalent innovations of the Law is related to the introduction of the means-tested approach to social service provision. Previously, all social services in public institutions were provided on free of charge basis. The new Law identifies different groups entitled to receive social services irrespective of the income (e.g. persons affected by trafficking in persons, persons affected by domestic or gender-based violence, children with disability, etc.), and for the rest, free social services are provided only if the average monthly total income is less than two subsistence wages. However, there is no mechanism for determining the right to a service, there are no calculation methods. Also, at the time of writing this paper, practitioners are asked whether those who started receiving free social services before January 1, 2020 will continue to receive such services in the future. In essence, the new rule looks like a narrowing of social rights and social guarantees, which is forbidden by the Constitution of Ukraine (Article 22.3). 
The disturbing challenge for the introduction of a new model of social services provides links to the low capacities of the local community to hire professionals capable of providing quality social services. For example, according to the Law an integrated social service for a family who has a child with a disability should include the following stages: 1) the family applies to the Center for Social Services in their united territorial community; 2 ) a highly skilled social work specialist (either social manager or case manager) assesses the needs of the family and develops an individual development plan; 3) specialist provides the case management of the family for a long time, according to needs, forwards its members to receive various comprehensive services in the community; assesses the progress of family development and makes adjustments to the action plan. It is expected that the family might have the access to the comprehensive and consistent delivery of services that may include early intervention services, inclusive resource centers, health care, inclusive education, and support for parents of positive parenting. Furthermore, a multidisciplinary team would work with the family and the child, which includes medical doctors, social educators, speech therapists, psychiatrists, psychologist and so on [5]. But researches show the low level of social workers competences, underdevelopment of the field social work education and lack of multidisciplinary approaches. Author [8] says: “ ...current social agencies can't provide quality and affordable social services at the level of local communities without being reformed. The same with social workers: they can work on the level of the community only after special training". The discussions with practitioners held in October 2019 fully support these discouraging findings.

The broader gap for the new legislation on social services implementation is connected to the unfinished decentralization reform per se. The academics stress that "Ukraine's Constitution does not yet reflect the new state of real affairs being created by the amalgamation of communities, their cooperation agreements, the new territorial-administrative order, the new revenue sources of communities', the changed delimitation of authority between local self-government and state administrations, as well as some other decentralization-related novelties in Ukrainian political and social life" [6]). This fully applies to the social services provision and roles of the key actors in this area. The undertaken analysis reveals that the local communities will not have real autonomy in decision-making regarding social services, as many aspects of the new model should be defined on the national level.

It will not be an exaggeration to point out the discrepancy between the legal forms established in Ukraine by the new Law "On Social Services" and the realities of the local communities. Normative, financial and human resources of Ukrainian local communities may not be enough for setting up an effective community-based model of social services expected by the Law.

\section{CONCLUSIONS}

The new Law of Ukraine "On Social Services", which formally comes into force in 2020, aims to introduce a new sufficiently extensive and professional system of basic social services, both voluntary and mandatory. This model is based on creating a market for such services with the local communities, enhancing their targeting and transparency. The legal regulation focuses on improving the management of the social services system in the context of decentralization and optimizing expenditures, ensuring uniform approaches in the organization of the system. It is expected that local self-government in Ukraine will have some new functional authorities and the ability to solve the existing local social problems.

The conducted analysis of the Law reveals several shortcomings, gaps, and challenges associated with the implementation of the new legislation. Firstly, the text of the Law provides an extensive and not always clear classification of social services from local governments. Secondly, the central authorities did not provide real mechanisms and organizational tools for the implementation of the new system; the anticipated by-laws were not adopted by the 1st of January, 2020. Thirdly, the awaited high level of social services is not corresponding to the existing lack of professionals in social work. It is possible to assume that the existing risks of regulatory, administrative and professional nature may jeopardize the feasibility of the Law implementation. Furthermore, the explicated challenges for social services provision may hinder the importance and prospectives of local self-government transformations in Ukraine, as problems may affect the perception of local authorities, local selfgovernment, and decentralization reform as a whole. 


\section{REFERENCES}

1. Association of Ukrainian Cities. (2019). How to execute the new law on social services without adopting by-laws. Retrieved from https://decentralization.gov.ua/en/news/12044

2. Cheremision, A. (2018). Modern decentralization of local self-government in Ukraine: sources and perspectives of development (regional aspect). Viešoji politika ir administravimas, 17(4), 555567.

3. On Social Services (Ukraine), 17.01.2019, No 2671-VIII. Retrieved from https://zakon.rada.gov.ua/laws/show/2671-19

4. Opening Doors. (2018). Ukraine: 2018 Country Fact Sheet. Retrieved from https://www.openingdoors.eu/wp-content/uploads/2019/03/country-fiche-Ukraine-2018.pdf

5. Postolyuk, H., Tatarchuk, N., Doyal, O., \& Gerasymchuk, F. (2018). Road map of reform: strong families, children protected: Guidelines for the child protection system at the district/inified territorial community level. Kyiv.

6. Rabinovych, M., Levitas, A., \& Umland, A. (2018). From Amalgamation of Local Communities to a New Governance System in Post-Euromaidan Ukraine. The New Eastern Europe. Retrieved from https://neweasterneurope.eu/2018/06/19/amalgamation-local-communities-newgovernance-system-post-euromaidan-ukraine

7. Rohovenko, O. V., Zapara, S. I., Melnik, N.M., \& Cramar, R. I. (2017). The current status of the local selfgovernment reform in Ukraine: preliminary conclusions and outlook. Journal of Advanced Research in Law and Economics, 8(23), 178-185.

8. Slozanska, H. (2017). Social services: are current state social agencies ready to provide them on the level of local communities in Ukraine (selective survey). Social Work and Education, 4(2), 77101.

9. Strutynskyi, V., \& Strutynska-Struk, L. (2019). Formation of the European local self-government model in Ukraine: developments and expectations. Political Preferences, 22, 5-18.

10. Tolkovanov, V. V. (2017). Territorial communities' cooperation (intermunicipal cooperation - IMC) as an innovative tool for ensuring local economic development and municipal consolidation. Naukovyy visnyk Polissya, 1(9), 76-80.

11. Vaskivska, K. V., Pelechatyj, A. O., Galimuk, J. O., \& Lozinska, L. D. (2019). Cooperation of territorial communities in conditions of decentralization. Efektyvna ekonomika, 8. Retrieved from http://www.economy.nayka.com.ua/?op=1\&z=7209 